\title{
Two Different Types of Sialoadenitis in the NOD- and MRL/Ipr Mouse Models for Sjögren's Syndrome: A Differential Role for Dendritic Cells in the Initiation of Sialoadenitis?
}

\author{
Saskia C.A. van Blokland, Cornelia G. van Helden-Meeuwsen, \\ Annet F. Wierenga-Wolf, Hemmo A. Drexhage, Herbert Hooijkaas, \\ Joop P. van de Merwe, and Marjan A. Versnel
}

Department of Immunology, Erasmus University Rotterdam and University Hospital Rotterdam - Dijkzigt, Rotterdam, The Netherlands

SUMMARY: Sjögren's syndrome is an autoimmune disease that primarily affects the salivary and lacrimal glands. In these glands, focal lymphocytic infiltrates develop. Little is known about the initiation of this autoimmune disease. Antigen-presenting cells (APC) such as dendritic cells (DC) can play a role in the initiation of autoimmunity. To date, no data on the presence of DC in Sjögren's syndrome are available. Several mouse strains, the nonobese diabetic (NOD) and the MRL/Ipr mouse, can be used as models for Sjögren's syndrome. We compared the development of sialoadenitis in the submandibular glands (SMG) of NOD and MRL/Ipr mice with particular focus on the presence of APC. DC, macrophages, T cells, and B cells in the SMG were studied by means of immunohistochemistry, after which positively stained cells were quantified. NOD-severe combined immunodeficiency (SCID) mice were used to study the presence of APC in the SMG in the absence of lymphocytes. Before lymphocytic infiltration, increased numbers of DC were detected in the SMG of NOD mice compared with those numbers in control mice and MRL/Ipr mice, which suggests that DC play a role in the initiation of sialoadenitis in NOD mice. In the SMG of NOD mice, lymphocytic infiltrates organized in time. In MRL/lpr mice, however, lymphocytic infiltrates were already organized at the time of appearance. This organization was lost over time. In conclusion, two types of sialoadenitis are described in two mouse models for Sjögren's syndrome. Differences exist with regard to early events that may lead to the development of sialoadenitis and to the composition and organization of inflammatory infiltrates. It is possible that different types of sialoadenitis also exist in humans and that the pathogenetic process in both the early and late phases of the autoimmune reaction differs among patients. (Lab Invest 2000, 80:575-585).

\begin{abstract}
S jögren's syndrome is a systemic autoimmune dis$\int$ ease with a chronic course that is characterized by lymphocytic infiltration and destruction of the salivary and lacrimal glands, which causes dryness of the mouth and eyes (Fox, 1995). A combination of immunologic, genetic, hormonal, and possibly also viral factors plays a role in the development of this multifactorial disease, but little is known about the early stages of Sjögren's syndrome that lead to the initiation of the autoimmune process (Aziz et al, 1992; Fox, 1996).

Several mouse models are used to study the pathogenesis of Sjögren's syndrome. Two of those models, the nonobese diabetic (NOD) mouse and the MRL/pr mouse, are widely accepted (Hayashi et al, 1994; Hoffman et al, 1984; Humphreys-Beher, 1996). In both mouse strains, perivascular and periductal lymphocytic infiltrates in the salivary and lacrimal glands are histo-
\end{abstract}

Received December 17, 1999.

Address reprint requests to: Dr. S. C. A. van Blokland, Department of Immunology, Erasmus University Rotterdam, P.O. Box 1738, 3000 DR Rotterdam, The Netherlands. Fax: $31 \quad 10408$ 9456; E-mail: vanblokland@immu.fgg.eur.nl logic hallmarks of the disease. In NOD mice (but not in MRL/pr mice) the development of focal lymphocytic infiltrates in the salivary glands (sialoadenitis) is accompanied by a corresponding loss of the secretory function and changes in the protein composition of the saliva (Humphreys-Beher, 1996; Humphreys-Beher et al, 1994). These changes in protein composition have also been observed in NOD-SCID (severe combined immunodeficiency) mice (Robinson et al, 1996). The NODSCID mouse is devoid of functional T lymphocytes and $B$ lymphocytes because of a homozygosity in the SCID mutation (Shultz et al, 1995). Hence the salivary gland abnormalities in this mouse strain must be considered as the cause rather than a consequence of the focal lymphocytic infiltration. In MRL/lpr mice, the systemic autoimmune response is accelerated compared with that in congenic MRL/Mp mice because of a mutation in the Fas apoptosis gene. This results in the failure of autoreactive lymphocytes to be deleted by means of apoptosis and causes an accumulation of these lymphocytes in the periphery (Watson et al, 1992; Wu et al, 1994).

With regard to the composition of the inflammatory infiltrates in the salivary glands of NOD mice, MRL/Ipr 
mice, and patients with Sjögren's syndrome, attention has been focused on the presence of various subsets of $T$ cells and $B$ cells. Most infiltrating lymphocytes are $\mathrm{TCR} \alpha \beta^{+}$and $\mathrm{CD} 4^{+}$T cells, whereas $\mathrm{CD} 8^{+} \mathrm{T}$ cells and $\mathrm{B}$ cells are fewer in number (Goillot et al, 1991; Jonsson et al, 1987; Yanagi et al, 1997). The development of sialoadenitis in the NOD- and the MRL/lpr mouse models for Sjögren's syndrome has never been compared over time.

For the activation of naive $\mathrm{T}$ cells, antigen from antigen-presenting cells (APC) such as dendritic cells (DC) must be present. In contrast to macrophages, mature DC have limited phagocytic activity but must constitutively express high levels of $\mathrm{MHC}$-class II and costimulatory molecules. Mature DC are the most potent regulators of the immune response ( Peters et al, 1996; Stingl and Bergstresser, 1995). Information on the topographic distribution of DC and macrophages before and during the development of sialoadenitis is scarce. In animal models of insulin-dependent diabetes mellitus and of autoimmune thyroiditis, DC and macrophages are the first cells of hematopoietic origin that infiltrate the target organ (Dahlen et al, 1998; Jansen et al, 1994; Rosmalen et al, 1997; Voorbij et al, 1989; Voorbij et al, 1990). The presence of these cells in the earliest stages of the disease suggests that they play an essential role in the initiation and regulation of the autoimmune reaction. In this study, immunohistochemical techniques were used to examine the development of sialoadenitis, particularly with respect to the topographic distribution of

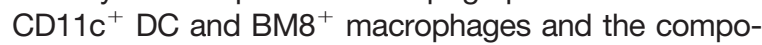
sition of the lymphocytic infiltrates, in the submandibular glands (SMG) of NOD mice and MRL/lpr mice from 2 to 20 weeks of age.

\section{Results}

\section{Development of Focal Lymphocytic Infiltrates in the Submandibular Glands of NOD Mice and MRL/Ipr Mice}

When sections of the submandibular glands (SMG) of 5-week-old NOD mice and MRL/lpr mice were compared, focal lymphocytic infiltrates were already present in 6 of $8 \mathrm{MRL} / \mathrm{lpr}$ mice. These infiltrates were demarcated areas of lymphocytes that had not infiltrated the surrounding parenchyma. In NOD mice, focal demarcated lymphocytic infiltrates were first detected at the age of 10 weeks and were more prominent at 20 weeks, yet the areas of infiltration were not as large as those in the MRL/Ipr mice (Fig. 1 $A$ and $E)$. In the latter mouse strain, the large focal infiltrates had lost their area of demarcation and had started to infiltrate the surrounding parenchyma when the mice were 20 weeks of age.

\section{Structure of the Focal Lymphocytic Infiltrates in the SMG of NOD Mice and MRL/Ipr Mice During the Development of Sialoadenitis}

The focal lymphocytic infiltrates in the SMG of 5-week-old MRL/lpr mice showed a certain degree of structure, with separate T-cell and B-cell areas (Fig. 2 $A$ and $B$ ). This structure had vanished in MRL/Ipr mice aged 20 weeks, and distinct T-cell and B-cell areas could no longer be identified (Fig. $1 \mathrm{E}$ and F), although the areas of infiltration had increased in size and lymphocytes had started to infiltrate the surrounding parenchyma. In NOD mice, the pattern of development of focal lymphocytic infiltrates was different from that in MRL/lpr mice. At 10 weeks, when focal lymphocytic infiltrates were detectable in NOD mice, there was no apparent structure; only at 20 weeks of age could clearly structured focal infiltrates be detected (Fig. $1 \mathrm{~A}$ and $\mathrm{B}$ ). Areas consisting predominantly of $\mathrm{B}$ cells could be distinguished, while packed $T$ cells were present in an area in which B cells were largely absent. $\mathrm{T}$ cells were also present as scattered cells in the B-cell area.

With regard to the presence of $C D 11 c^{+} \mathrm{DC}$ in the focal lymphocytic infiltrates, the density of CD11c ${ }^{+}$ DC was highest in the packed T-cell area of 20-weekold NOD mice (Fig. 1C). In the SMG of 20-week-old $\mathrm{MRL} / \mathrm{Ipr}$ mice, DC were distributed throughout the whole lymphocytic infiltrate (Fig. 1G). $\mathrm{BM}^{+}$macrophages were detected in the SMG of NOD and MRL/ Ipr mice of all ages, but the spatial relation of those macrophages towards the focal lymphocytic infiltrates differed in the two mouse strains (Figs. $1 \mathrm{D}$ and $\mathrm{H}$ and 2D). In the SMG of 20-week-old NOD mice, a thin rim of $\mathrm{BM}^{+}$macrophages was present around lymphocytic infiltrates (Fig. 1D). In MRL/lpr mice, a thicker rim of $\mathrm{BM}^{+}$macrophages was present around the lymphocytic infiltrates. In addition, these cells invaded the lymphocytic infiltrates to a certain extent (Fig. 1H).

These results show that qualitative differences exist between the focal lymphocytic infiltrates that develop in the SMG of NOD mice as compared with those in MRL/Ipr mice.

\section{Image Analysis of the Lymphocytic Infiltrates Present Within the Submandibular Glands of NOD Mice and MRL/Ipr Mice}

Image analysis revealed that at the onset of the development of focal lymphocytic infiltrates in the two mouse strains, no significant differences occurred in the percentages of $\mathrm{T}$ lymphocytes and $\mathrm{B}$ lymphocytes in the focal infiltrates (Table 1). When the mice were 20 weeks old, the percentage of B cells in the fully developed focal infiltrates of the NOD mice was significantly higher than that in the MRL/lpr mice. In contrast to the percentage of B cells, the percentage of $\mathrm{T}$ lymphocytes in the focal lymphocytic infiltrates was significantly higher in 20-week-old MRL/lpr mice than in age-matched NOD mice. Over time, an increase in the percentage of $\mathrm{B}$ cells and a significant decrease in the percentage of T cells in the lymphocytic infiltrates of NOD mice were observed. However, this was not statistically significant. In MRL/lpr mice, a decrease in the percentage of $B$ cells and an increase in the percentage of $T$ cells that was not significant were observed. The decrease in the percentage of $B$ cells in aging MRL/lpr mice was also obvious from immunohistochemical stainings (Figs. $1 \mathrm{~F}$ and $2 \mathrm{~B}$ ). 


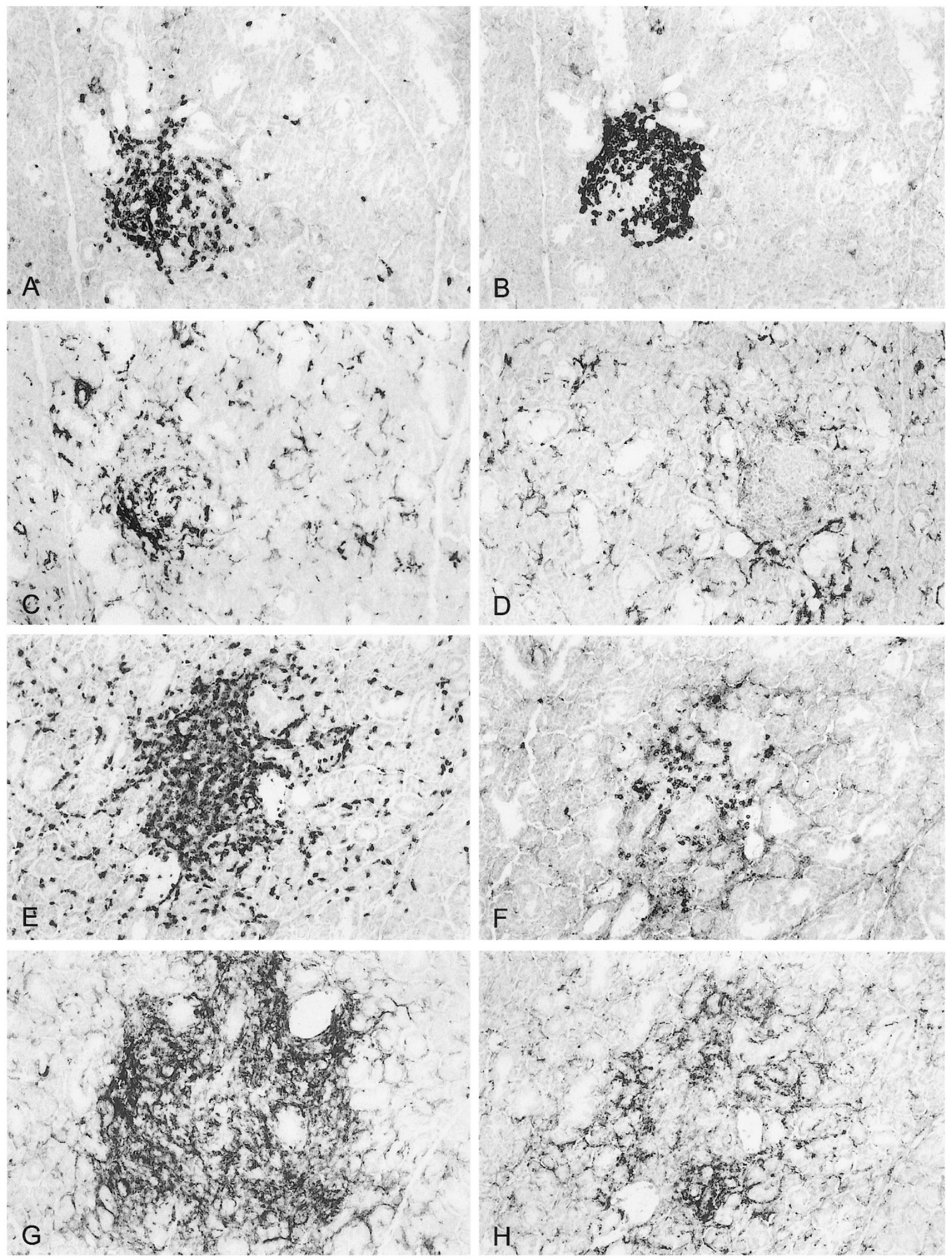

\section{Figure 1.}

Immunohistochemical detection of leukocyte subsets in serial sections of lymphocytic infiltrates in a submandibular gland (SMG) of a 20-week-old nonobese diabetic (NOD) mouse and a 20-week-old MRL/Ipr mouse, respectively. A to D, NOD mouse; $E$ to $\mathrm{H}$ : MRL/lpr mouse. A and E, T cells identified by the MoAb KT3. B and F, B cells identified by the MoAb B220. C and G, CD11c ${ }^{+}$dendritic cells identified by the MoAb N418. D and H: BM8 ${ }^{+}$macrophages $(\times 200)$. 

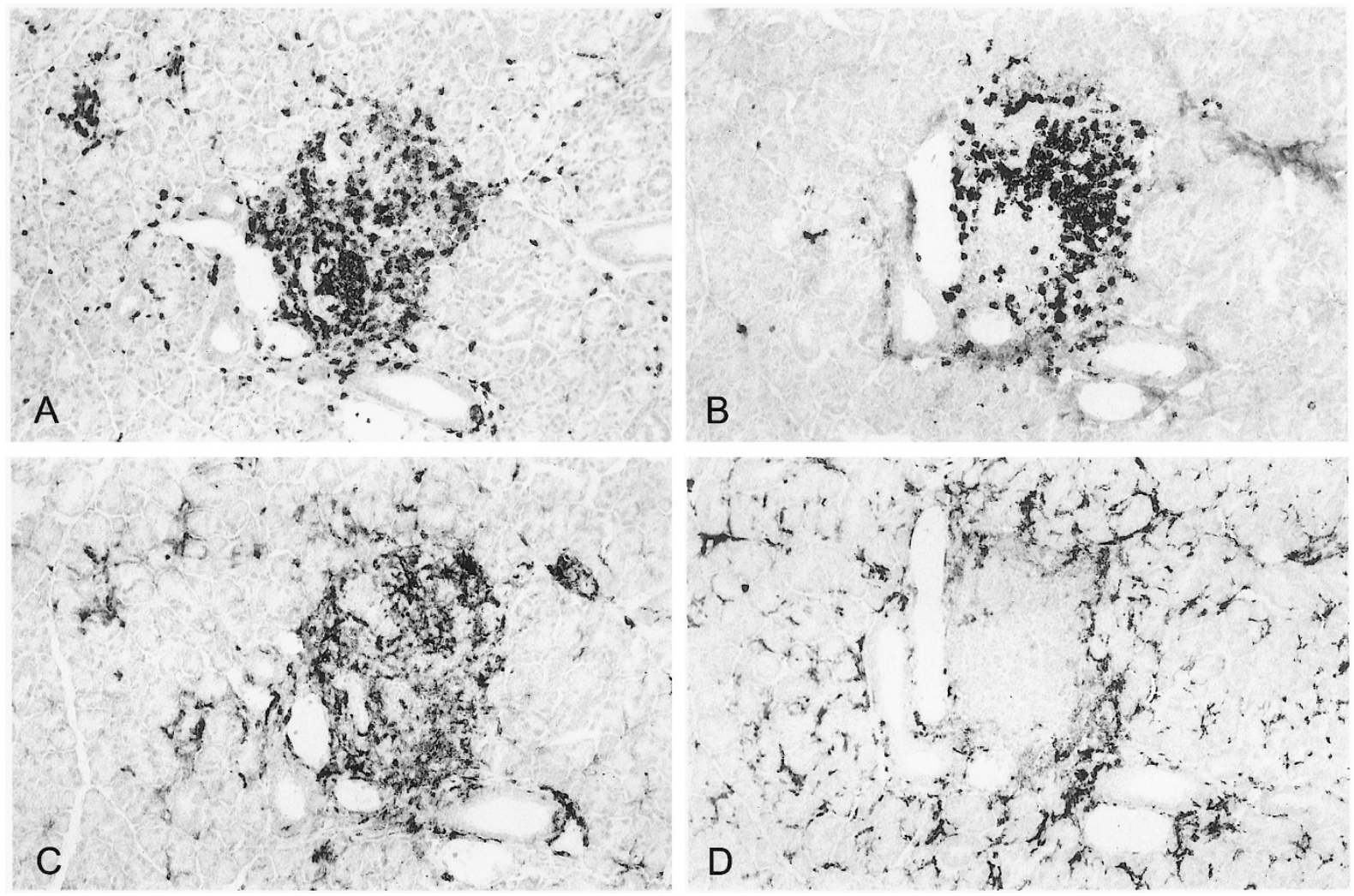

Figure 2.

Immunohistochemical detection of leukocyte subsets in serial sections of a lymphocytic infiltrate showing some degree of organization in the SMG of a 5-week-old MRL/Ipr mouse. A, T cells identified by the MoAb KT3. B, B cells identified by the MoAb B220. C, CD11c ${ }^{+}$dendritic cells identified by the MoAb N418. D, BM8 ${ }^{+}$ macrophages $(\times 200)$.

Table 1. Composition of Lymphocytic Infiltrates Present Within Submandibular Glands of Nonobese Diabetic- and MRL/Ipr Mice

\begin{tabular}{|c|c|c|c|}
\hline Strain & $\begin{array}{c}\text { Age } \\
\text { (weeks) }\end{array}$ & B cells $(\%)^{\mathrm{a}}$ & $\mathrm{T}$ cells $(\%)^{\mathrm{a}}$ \\
\hline NOD & 10 & $24.7 \pm 8.5$ & $29.5 \pm 4.0$ \\
\hline NOD & 15 & $33.3 \pm 2.7$ & $28.5 \pm 6.0$ \\
\hline NOD & 20 & $35.2 \pm 3.2$ & $26.7 \pm 3.7$ \\
\hline MRL/lpr & 5 & $27.0 \pm 3.2$ & $28.1 \pm 5.4$ \\
\hline MRL/lpr & 10 & $23.5 \pm 2.3^{\star b}$ & $32.0 \pm 2.5$ \\
\hline MRL/lpr & 15 & $19.7 \pm 1.8^{\star \# \mathrm{c}}$ & $32.1 \pm 3.8$ \\
\hline MRL/pr & 20 & $17.8 \pm 2.3^{\#}$ & $34.4 \pm 2.1^{\#}$ \\
\hline
\end{tabular}

${ }^{a}$ Values are given as the mean \pm standard deviation.

${ }^{b}$ Statistical comparison of time point with the previous time point by the Mann-Whitney two-sample two-tailed signed rank test $\left({ }^{*} p<0.05\right)$.

${ }^{c}$ Statistical comparison of MRL/pr mice with age-matched NOD mice by the Mann-Whitney two-sample two-tailed signed rank test $\left({ }^{\#} p<0.05\right)$. NOD, Nonobese diabetic

\section{Presence of CD11C ${ }^{+}$Dendritic Cells During the Development of Sialoadenitis in NOD Mice and MRL/Ipr Mice}

Because of the important role of $D C$ in the activation of naive $T$ lymphocytes, we studied the presence of $D C$ in the SMG of NOD mice and MRL/lpr mice during the development of sialoadenitis. In glands of 5-week-old NOD mice (before lymphocytic infiltration) and NOD-
SCID mice, $\mathrm{CD} 11 \mathrm{c}^{+}$cells with dendritic morphologic characteristics were scattered throughout the parenchyma of the gland. DC were scarce or absent in the SMG of 5-week-old BALB/c and C57BL/10 mice (Fig. 3). Quantification by image analysis indicated that significantly more DC were present in the SMG of 5 -week-old NOD and NOD-SCID mice than in control strains (Fig. 4). To check for the earliest time point of DC infiltration in the SMG of NOD and NOD-SCID mice, we studied only a few SMG of 2-week-old mice. Hardly any DC were detected in the SMG glands (Fig. 5 ), which indicates that DC influx occurred between the age of 2 and 5 weeks.

When the influx of DC into the parenchyma of the SMG of NOD and NOD-SCID mice was studied over time, a steady increase in the number of $\mathrm{CD} 11 \mathrm{c}^{+}$cells was observed until the mice were 15 weeks old, although the increase was less pronounced in NOD-SCID mice than in NOD mice (Fig. 5). In both mouse strains, a plateau was reached at the age of 15 weeks. The steady increase in DC numbers was not observed in BALB/C mice and C57BL/10 mice, which indicates that the phenomenon is not a general consequence of aging.

Few DC were present in the parenchyma of the SMG of 5-week-old MRL/pr mice; this is comparable in C57BL/10 mice (Fig. $3 \mathrm{C}$ and E). Because focal lymphocytic infiltrates were already present in this mouse strain at the age of 5 weeks, the virtual absence of DC at this 

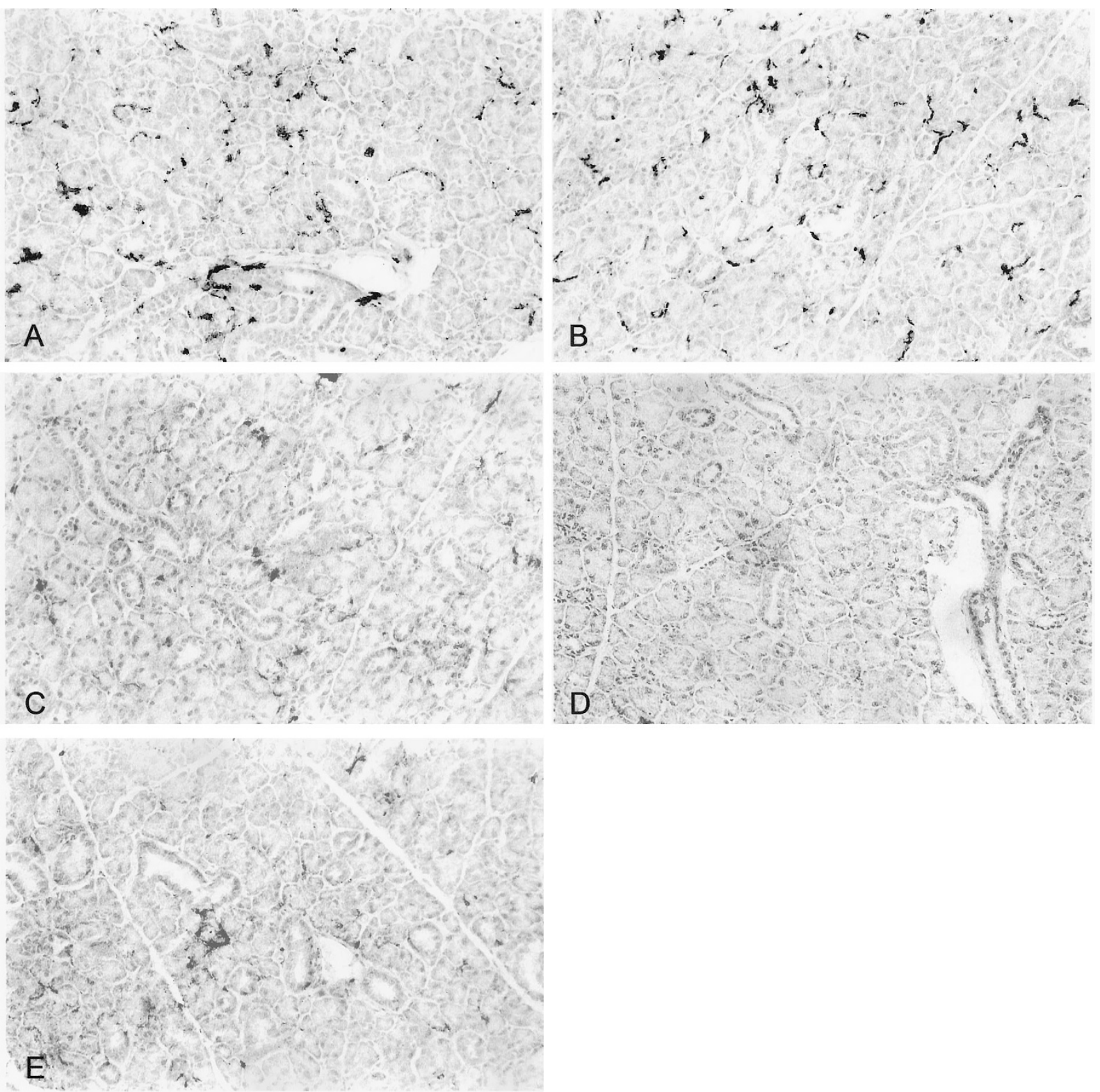

\section{Figure 3.}

Immunohistochemical detection of dendritic cells (DC) in the parenchyma of SMG sections of 5-week-old mice as revealed by the monoclonal antibody N418. A, NOD mouse. B, NOD-SCID mouse. C, C57BL/10 mouse. D, BALB/c mouse. E, MRL/Ipr mouse $(\times 200)$.

age does not exclude a possible influx of DC into the SMG of MRL/lpr mice at an earlier time. To examine the relationship between $\mathrm{DC}$ and the first appearance of lymphocyte accumulation in the SMG of the two mouse strains, a detailed analysis on the presence of $D C$ and $T$ lymphocytes in the SMG of MRL/pr and NOD mice that were 1 to 5 weeks old was performed (Fig. 6). In the SMG of 1-week-old MRL/pr mice, hardly any dendritic cells were present, which was comparable to the situation in 2-week-old NOD, NOD-SCID, and control mice. However, scattered T lymphocytes were already detected in the glandular tissue of those MRL/lpr mice. Accumulations of lymphocytes were present in the SMG of 3 of 5 MRL/pr mice that were 2 weeks old, and the number of scattered T lymphocytes had increased. In the surrounding parenchyma, very few DC were present. Small lym- phocytic infiltrates were detected in the SMG of 4-weekold MRL/pr mice, while a slight increase in the number of dendritic cells was observed. In the SMG of MRL/pr mice 6 to 20 weeks old, the increase in the number of DC in the parenchymatous tissue of the gland was modest over time (results not shown). Still, numbers of DC were clearly lower in 20-week-old MRL/pr mice than in NOD mice of the same age.

\section{Discussion}

This study shows two distinct patterns of autoimmune sialoadenitis development in the NOD mouse and the MRL/pr mouse, which are two models for Sjögren's syndrome. In NOD mice, the presence of focal lymphocytic infiltrates (first not structured and later with $\mathrm{T}$ cell and B cell 


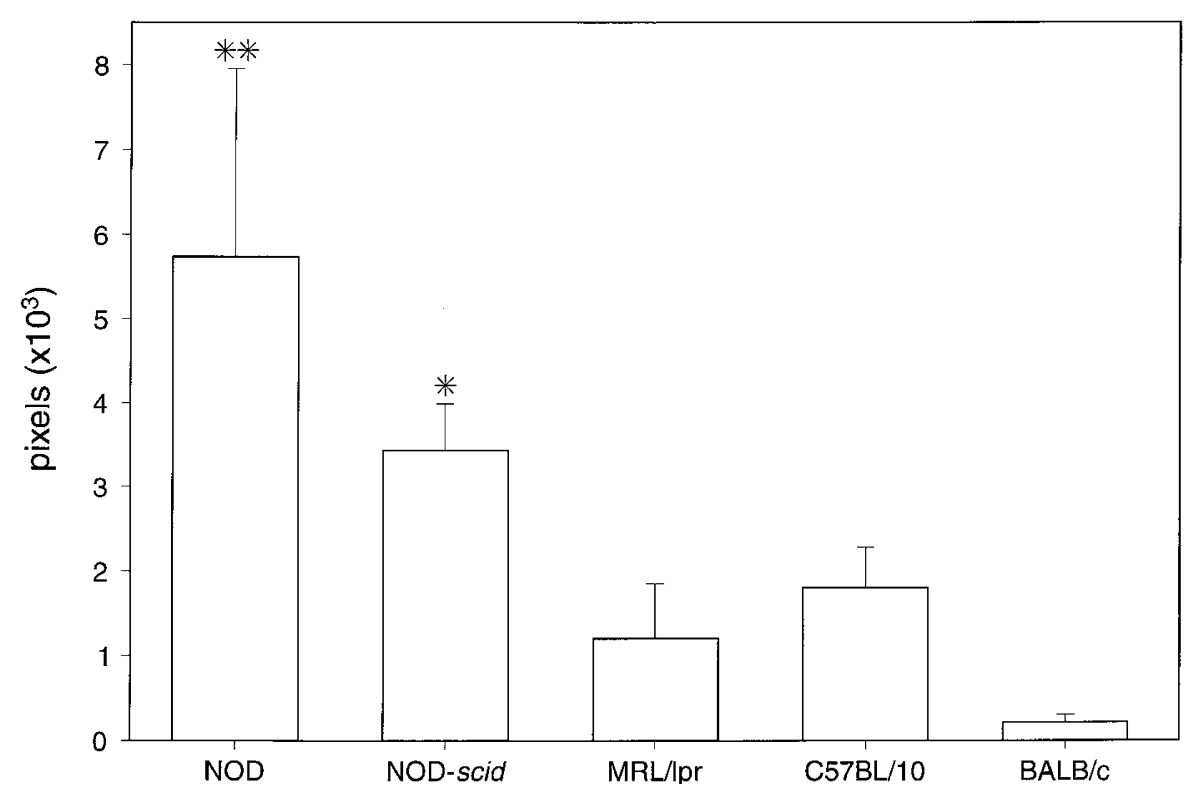

\section{Figure 4.}

DC in the SMG of 5-week-old mice. After having undergone immunohistochemical staining with MoAb N418 to identify CD11c positive DC, positively stained cells were quantified by two independent individuals who used an image analysis system. Values are expressed as means \pm SD of 4 to 8 animals per group. Statistical analysis was performed by the Mann-Whitney two-sample two-tailed signed rank test. NOD, Nonobese diabetic mice; NOD-SCID, nonobese diabetic severe combined immunodeficiency mice. ${ }^{*}$ Significantly different as compared with C57BL/10 mice, $p<0.01$. * Significantly different as compared with C57BL/10 mice, $p<0.005$.

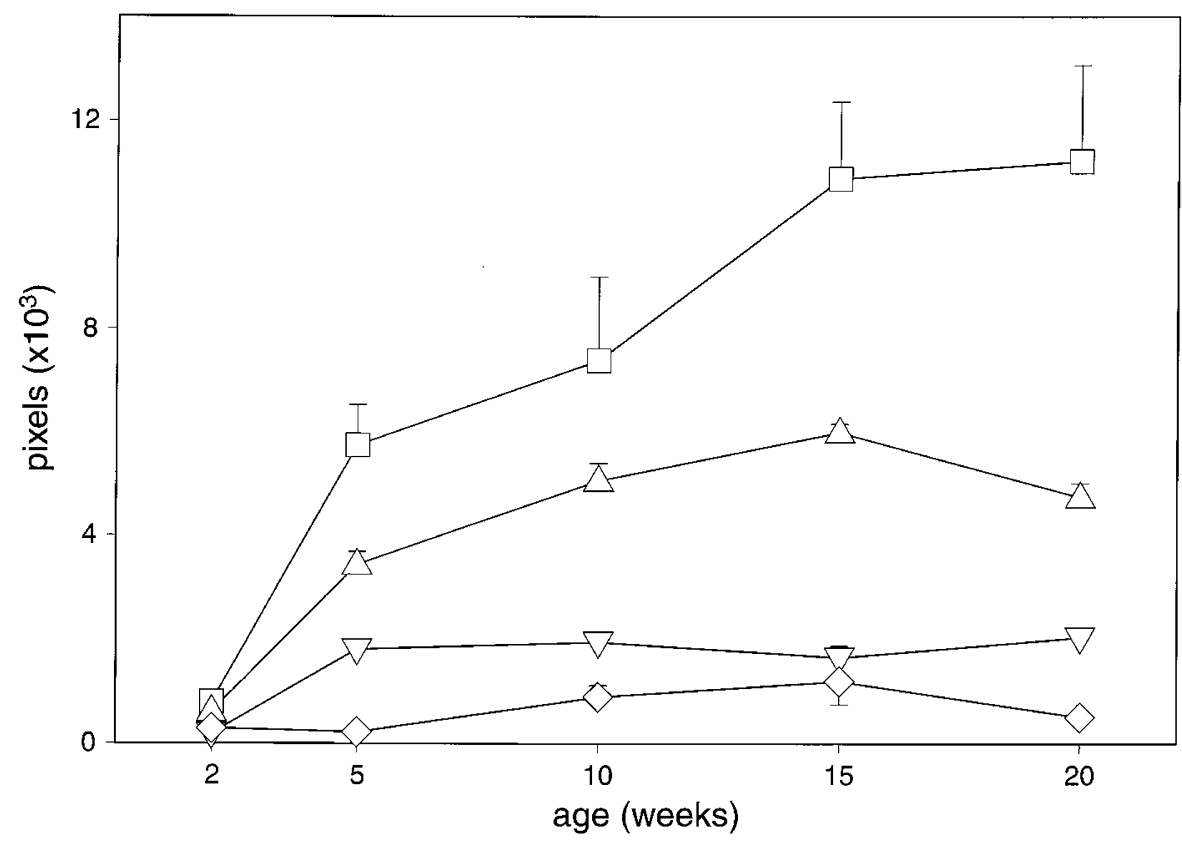

\section{Figure 5.}

DC in the SMG of different mouse strains over time. After having undergone immunohistochemical staining with MoAb N418, positively stained cells were quantified by two independent individuals who used an image analysis system. Values are expressed as means \pm standard errors of the means. Values that were measured in the SMG of NOD or NOD-SCID mice 5 weeks of age or older were significantly different when compared with values that were measured in the glands of the other mouse strains $(p, 0.001<p<0.05)$. However, there was no significant difference between 10-week-old NOD and NOD-SCID mice. $\square=$ NOD, nonobese diabetic mice; $\Delta=$ NOD-SCID, nonobese diabetic severe combined immunodeficiency mice; $\nabla=\mathrm{C} 57 \mathrm{BL} / 10 ; \diamond=\mathrm{BALB} / \mathrm{c}$.

areas) was first observed when the mice were 10 weeks old and was preceded by an influx of DC that began between the age of 2 and 5 weeks. This influx of DC was in both independent of and dependent on the presence of lymphocytes, because such an influx was also observed in NOD-
SCID mice, but to a lesser degree. NOD-SCID mice lack functional $\mathrm{T}$ lymphocytes and $\mathrm{B}$ lymphocytes.

In the SMG of MRL/lpr mice, focal lymphocytic infiltrates were already present at the age of 5 weeks, while first signs of lymphocytic accumulation were 


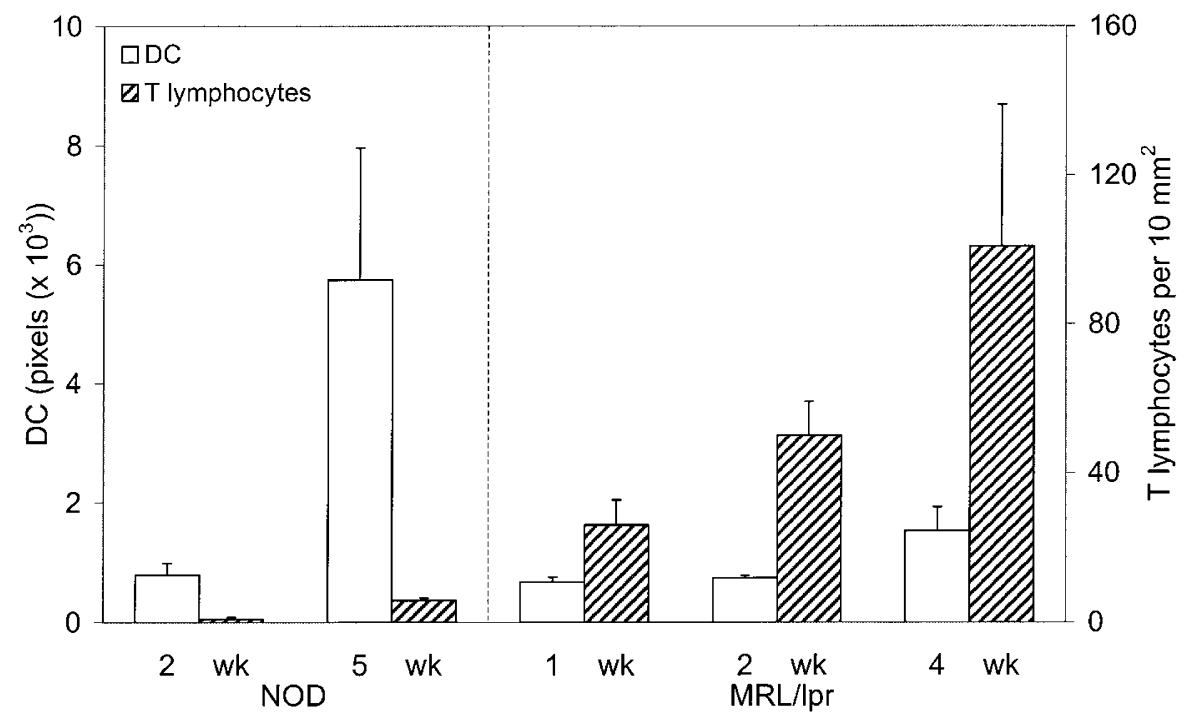

\section{Figure 6.}

Analysis of DC and T lymphocytes in the SMG of NOD and MRL/Ipr mice that were 1 to 5 weeks old. Positively stained DC were quantified by two independent individuals who used an image analysis system (left $\mathrm{y}$-axis). The numbers of positively stained $\mathrm{T}$ lymphocytes were counted per $10 \mathrm{~mm}^{2} \mathrm{glandular}$ tissue by two independent individuals (right y-axis). Values are expressed as means \pm standard deviation of 5 animals per group. DC, Dendritic cells; NOD, nonobese diabetic mice.

already observed at the age of 2 weeks. The virtual absence of DC in the SMG of 1-week-old MRL/lpr mice shows that the development of focal lymphocytic infiltrates in this mouse strain is not preceded by an influx of DC in the parenchyma of the gland. Because slightly increased numbers of DC in the parenchyma of the SMG were observed in mice $\geq 4$ weeks old (ages at which lymphocytic infiltrates had started to develop), it can be concluded that DC in MRL/lpr mice $\geq 4$ weeks old are due to the presence of lymphocytic infiltrates.

These two distinct patterns of DC influx and focal infiltrate development in the two mouse models suggest two distinct patterns of disease pathogenesis. With regard to the early $D C$ accumulation in the parenchyma of the SMG of NOD mice before any noteworthy lymphocytic infiltration, it is likely that DC pick up autoantigens in the SMG of the NOD and travel to the draining lymph node. In the lymph node, $\mathrm{DC}$ activate naive $\mathrm{T}$ cells to initiate the autoimmune process, which later leads to the focal accumulation of T cells in the SMG. The traffic of DC through tissues is tightly regulated by chemokine receptor expression on the cells. During their maturation from monocytes, DC express various combinations of chemokine receptors that enable monocytes and DC, depending on their maturational stage, to respond to different chemokines (Sozzani et al, 1997; Xu et al, 1996). The migration of epidermal Langerhans cells and dermal DC can be enhanced by the cytokines IL-1 $\beta$ and TNF- $\alpha$ (Zanella et al, 1996). Recently, chemokine expression in the minor salivary glands (MSG) of patients with Sjögren's syndrome has been described, and ductal epithelial cells were identified as the predominant source of chemokines in the MSG (Cuello et al, 1998). An increased expression of the cytokines IL-1 $\alpha$, IL-1 $\beta$, TNF- $\alpha$, and IL- 6 by salivary gland epithelial cells of Sjögren's syndrome patients when compared with controls has been observed ( Boumba et al, 1995; Fox et al, 1994; Oxholm et al, 1992). These studies illustrate the capability of epithelial cells of the salivary glands to express cytokines that may attract DC. Such enhanced chemokine-cytokine expression might be linked to a metabolic abnormality or disturbed proliferation of the salivary gland epithelial cells of the NOD mouse; note that changes in the salivary protein composition in aging NOD mice have been observed (Humphreys-Beher, 1996; Humphreys-Beher et al, 1994). Early metabolic and/or growth abnormalities that precede the DC influx have also been noted in the thyroid gland of the biobreeding diabetes-prone rat, in which autoimmune thyroiditis develops after the influx of DC (Simons et al, 1998).

In MRL/lpr mice, the focal sialoadenitis started in the virtual absence of DC in the parenchyma at a much earlier age than in NOD mice. This suggests that the SMG epithelial cells are not the initial driving force behind the autoimmune process. It is possible that in $\mathrm{MRL} / \mathrm{lpr}$ mice, $\mathrm{T}$ cells and B cells, sensitized to an autoantigen that is not primarily expressed in the salivary glands, are already present from a very early age. This antigen might be of nuclear origin, like double-stranded deoxyribonucleic acid. The production of antibodies towards such an autoantigen can lead to the formation of immune complexes and to the deposition of these complexes in the small vessels, which is followed by vasculitis. Sensitization of lymphocytes is in that case not primarily mediated by APC coming from the salivary gland but instead takes place elsewhere in the body.

Another important difference between sialoadenitis in NOD and MRL/lpr mice was the architecture of the focal lymphocytic infiltrates. In both mouse models, focal lymphocytic infiltrates developed during the course of the disease. The lymphocytic infiltration occurred in NOD mice 10 weeks of age and older and 
gradually gained structure with $\mathrm{T}$-cell and $\mathrm{B}$-cell areas. In 5-week-old MRL/lpr mice, structured focal infiltrates were already present, but that structure was lost over time.

What is the function of the organized focal lymphocytic infiltrates that develop in the SMG of both strains of mice? Similarly organized structures have been observed in other animal models of organ-specific autoimmune disease, eg, the thyroid gland of the biobreeding diabetes-prone rat (Mooij et al, 1993) and the pancreas of the NOD mouse (Lo et al, 1993). These organized focal infiltrates, some aspects of which resemble normal lymph node and gut-bronchus associated lymphoid tissue, can be places of peripheral T-cell and B-cell sensitization to serve local generation of autoreactive $T$ cells and the production of autoantibodies. In the biobreeding diabetes-prone rat, a correlation was observed between the development of intrathyroidal focal lymphoid cell infiltrates and the incidence of anticolloid antibodies, which suggests that within such organized lymphoid structures, thyroid autoantibodies are produced (Mooij et al, 1993). A continued presence or release of antigen from the salivary gland is a probable driving force behind the development of the SMG-associated lymphoid tissue: De novo formation of organized lymphoid structures after repeated challenge with an organ-specific antigen was recently observed in a transgenic diabetic mouse model. Transgenic mice expressing the lymphocytic choriomeningitis virus glycoprotein under the control of the rat insulin promotor were immunized with DC that expressed an immunodominant cytotoxic T-lymphocyte epitope of the viral glycoprotein. Pancreatic islet associated organized lymphoid structures developed in these mice in addition to destructive autoimmune diabetes (Ludewig et al, 1998). In the MSG of two patients with Sjögren's syndrome, organized lymphocytic infiltrates have recently been described (Stott et al, 1998). In an MSG of one of these patients, fully developed germinal centers surrounded by large numbers of plasma cells were detected. It was suggested that the continued presence of selfantigen in the salivary gland was responsible for the development of these highly organized structures. Anti-Ro/SSA and anti-La/SSB autoantibodyproducing cells have been detected in the MSG of patients with Sjögren's syndrome. (Tengner et al, 1998).

When the composition of the focal inflammatory infiltrates was studied, a higher percentage of B cells was observed in 15- or 20-week-old NOD mice than in 10-week-old NOD mice. This age-related increase was not observed in MRL/lpr mice. We believe that this is due to a different pattern of cytokine production by the cells of the inflammatory infiltrates. The high number of $\mathrm{T}$ cells and of $\mathrm{BM}^{+}$macrophages in the focal infiltrates present in the SMG of MRL/lpr mice suggests the overproduction of proinflammatory Th1 cytokines that are important in the stimulation of cellular immune reactions. Far fewer $\mathrm{BM}^{+}$macrophages and a predominance of $\mathrm{B}$ cells were observed in the SMG of NOD mice when compared with the
SMG of MRL/lpr mice. This picture would fit more into a Th2-type reaction.

Despite our histologic observation that the glandular tissue in the SMG of 20-week-old MRL/lpr mice was more damaged, a decreased stimulated saliva production in this mouse strain has not been reported. This is in contrast to what has been described for the saliva production in NOD mice ( Humphreys-Beher, 1996; Humphreys-Beher et al, 1994), in which we did not find signs of parenchymal decay. The lack of glandular hypofunction in the MRL/lpr mouse in spite of signs of destruction of glandular tissue is explained by the fact that in general, a major part of the glandular tissue must be destroyed before an insufficient production of glandular product results. In NOD mice, salivary gland hypofunction is probably mediated by blocking antibodies, because salivary gland hypofunction could be transferred to young NOD mice by intraperitoneal injection of serum from old NOD mice (Esch and Taubman, 1998). This again emphasizes the importance of Th2 type reactivity in this model of Sjögren's disease. Moreover, the intrinsic abnormalities of the NOD salivary gland epithelial cells may play a role here.

If our data are extrapolated from mice to humans, different pathogenetic mechanisms for sialoadenitis (Sjögren's syndrome) exist. NOD-like sialoadenitis would follow the pattern of development of the known other organ-specific autoimmune diseases such as type 1 diabetes and thyroiditis. This primary form of Sjögren's syndrome is characterized by an antigen of salivary gland origin and perhaps a histopathologic picture akin to that of the NOD mouse: structured focal infiltrates, a predominance of $B$ cells within the infiltrates, and a strong parenchymal infiltration of DC. MRL/Ipr-like sialoadenitis would follow a different pattern of development. This form would be secondary and would be associated with systemic autoimmune disorders and perhaps a histopathologic picture akin to that of the MRL/lpr mouse: unstructured focal infiltrates, a predominance of $T$ cells within the infiltrates, and a parenchymal infiltration with predominantly scavenger macrophages. Our data in the animal models indicate that a detailed analysis of the composition of the infiltrates in the MSG of patients with Sjögren's syndrome (B cells, T cell, DC, macrophages) is worthwhile for a differential diagnosis. This subject will form the core of our next report.

\section{Materials and Methods}

\section{Mice and Experimental Design}

Female NOD, NOD-SCID, C57BL/10, and BALB/C mice were bred in our own facilities under specific pathogen-free conditions. Female MRL/Ipr mice were purchased from Jackson Laboratories (Bar Harbor, Maine). Mice ( $n=4$ to 8 mice/age/strain) were fed standard pellets and water ad libitum and were maintained at $22+/-1^{\circ} \mathrm{C}$ on a 12-hour light/12-hour dark cycle. Under these conditions, the incidence of diabetes in NOD mice at 30 weeks of age was $90 \%$ in females and $30 \%$ in males. 


\section{Tissue Preparation}

At the age of 1 to 6 weeks or $8,10,15$, or 20 weeks, the mice were killed by asphyxiation with carbon dioxide. The SMG were removed, were embedded in Tissue-tek (Sakura Finetek, Torrance, California), and were snap-frozen in liquid nitrogen. Tissues were stored at $-80^{\circ} \mathrm{C}$.

\section{Immunohistochemistry}

Microscopic slides were treated with 95\% ethanol/5\% diethylether solution for 10 minutes and were coated with a solution of $0.1 \%$ gelatin with $0.01 \%$ chromiumalum in distilled water. Thereafter, $6 \mu \mathrm{m}$ sections of the frozen tissue specimens were cut and fixed for 2 minutes. For this fixation, $0.4 \mathrm{gm}$ of pararosanilin (Sigma, St. Louis, Missouri) was dissolved in $10 \mathrm{ml}$ of 2 mole $\mathrm{HCl}$ by gently heating to $37^{\circ} \mathrm{C}$ for 4 hours; this was subsequently filtered and was stored at $4^{\circ} \mathrm{C}$. Of this stock solution, $500 \mu \mathrm{l}$ was incubated with $500 \mu \mathrm{l}$ $4 \% \mathrm{NaNO}_{2}$ for 1 minute. This was then added to 165 $\mathrm{ml}$ of distilled water in which the slides were fixed. After the fixation, the slides were rinsed in phosphatebuffered saline (PBS) ( $\mathrm{pH} 7.8) /$ Tween (0.1\%), after which they were incubated for 1 hour with the monoclonal antibody N418 (Metlay et al, 1990), KT3 (Tomonari, 1988), B220 (Ledbetter and Herzenberg, 1979), or BM8 (Malorny et al, 1986). Except for BM8 (BMA, Biomedical AG, Augst, Switzerland), all monoclonal antibodies were hybridoma culture supernatants reacting with $\mathrm{DC}$, total $\mathrm{T}$ cells, and $\mathrm{B}$ cells, respectively. As a negative control for these antibodies, the culture supernatant of cell line Y3 (the fusion partner that was used for the generation of the hybridoma cell line) was used. BM8, reacting with mature macrophages, was diluted 1:40 in PBS/Tween. After the incubation period, the slides were washed with PBS/Tween and were incubated for 40 minutes with a horseradish peroxidase-conjugated goat antiArmenian hamster IgG as a second antibody in case N418 was used as primary antibody (Jackson, ImmunoResearch Laboratories, West Grove, Pennsylvania). This antibody was diluted 1:100 in PBS/Tween to which $2 \%$ normal mouse serum was added to reduce background staining. In case KT3, B220, or BM8 was used as primary antibody, the slides were incubated for 40 minutes with horseradish peroxidaseconjugated rabbit antirat IgG (DAKO, Glostrup, Denmark) as second antibody. That antibody was diluted $1: 100$ in PBS/Tween to which $2 \%$ normal mouse serum was added. After having been washed in PBS/ Tween, the peroxidase label was developed by exposure to $0.10 \%(\mathrm{w} / \mathrm{v})$ diaminobenzidine in acetate buffer $(\mathrm{pH}, 6.0)$ containing $1 \% \mathrm{NiSO}_{4}(\mathrm{w} / \mathrm{v})$ and $0.02 \% \mathrm{H}_{2} \mathrm{O}_{2}$ for 3 minutes. The slides were washed in PBS/Tween, were counterstained by nuclear fast red $[0.1 \%(\mathrm{w} / \mathrm{v})$ solution in water containing $\left.5 \%(\mathrm{w} / \mathrm{v}) \mathrm{Al}_{2}\left(\mathrm{SO}_{4}\right)_{3}\right]$, and were dehydrated by an ethanol/xylene series and embedded with Depex mounting medium $(\mathrm{BDH}$, Poole, England).

\section{Image Analysis}

For quantitative analysis of sections, the VIDAS-RT image analysis system (Kontron Elektronik GmbH/Carl Zeiss, Weesp, The Netherlands) was used. All sections were analyzed by two independent individuals. Enumeration of cells expressing the N418 cell surface marker was performed as follows: At a magnification of 100,5 areas of the microscopic slides, which were located outside lymphocytic infiltrates, were counted. No part of a lymphocytic infiltrate was present in these areas. One area consisted of 262,144 pixels, the surface area of 10,000 pixels being $11,326 \mu \mathrm{m}^{2}$. After image capture, background color was excluded by image thresholding, after which the diaminobenzidine reaction product was quantified. Results were expressed as the mean number of positive pixels per area. The percentage of the total area of the lymphocytic infiltrates, which was positive for KT3 or B220, was determined as follows: At a magnification of 100 , the total surface area of each infiltrate was measured by drawing a line around the infiltrate. Then the total number of pixels within this area was determined. After image thresholding, the number of diaminobenzidine positive pixels within the inflammatory infiltrate was quantified. This value was divided by the total area of the lymphocytic infiltrate (in pixels) to determine a percentage of the area of the infiltrates that stained positive for one of the lymphocytic markers. The number of infiltrates analyzed within each gland varied from 1 to 8 , depending on how many infiltrates were present. If more than 8 infiltrates were present, the infiltrates to be analyzed were randomly chosen. Microscopic analysis of levels of $T$ lymphocytes present in SMG of NOD and MRL/lpr mice was performed by counting the numbers of $\mathrm{KT}^{+}$cells in 2 to 4 areas of $10 \mathrm{~mm}^{2}$ glandular tissue per mouse. Five mice per age group in both mouse strains were evaluated.

\section{Statistical Analysis}

The values measured within the gland of a single mouse were averaged, after which the means of the groups were calculated. The differences between the means were evaluated by means of the Mann-Whitney two-sample two-tailed signed rank test. A $p$ value $<$ 0.05 was considered statistically significant.

\section{Acknowledgements}

We gratefully acknowledge Professor Dr. R. Benner for critical reading of the manuscript, Mr. T.M. van Os for photographic assistance and preparation of the figures, and Mr. J. Brandenburg for care of the animals.

\section{References}

Aziz KE, Montanaro A, McCluskey PJ, and Wakefield D (1992). Sjogren's syndrome: Review with recent insights into immunopathogenesis. Aust N Z J Med 22:671-678. 
Boumba D, Skopouli FN, and Moutsopoulos HM (1995). Cytokine mRNA expression in the labial salivary gland tissues from patients with primary Sjogren's syndrome. Br J Rheumatol 34:326-333.

Cuello C, Palladinetti P, Tedla N, Di Girolamo N, Lloyd AR, McCluskey PJ, and Wakefield D (1998). Chemokine expression and leucocyte infiltration in Sjogren's syndrome. Br J Rheumatol 37:779-783.

Dahlen E, Dawe K, Ohlsson L, and Hedlund G (1998). Dendritic cells and macrophages are the first and major producers of TNF-alpha in pancreatic islets in the nonobese diabetic mouse. J Immunol 160:3585-3593.

Esch TR and Taubman MA (1998). Autoantibodies in salivary hypofunction in the NOD mouse. Ann N Y Acad Sci 842:221228.

Fox RI (1995). Sjogren's syndrome. Curr Opin Rheumatol 7:409-416.

Fox RI (1996). Clinical features, pathogenesis, and treatment of Sjogren's syndrome. Curr Opin Rheumatol 1996; 8:438445.

Fox RI, Kang HI, Ando D, Abrams J, and Pisa E (1994). Cytokine mRNA expression in salivary gland biopsies of Sjogren's syndrome. J Immunol 152:5532-5539.

Goillot E, Mutin M, and Touraine JL (1991). Sialadenitis in nonobese diabetic mice: Transfer into syngeneic healthy neonates by splenic T lymphocytes. Clin Immunol Immunopathol 59:462-473.

Hayashi Y, Haneji N, and Hamano H (1994). Pathogenesis of Sjogren's syndrome-like autoimmune lesions in MRL/Ipr mice. Pathol Int 44:559-568.

Hoffman RW, Alspaugh MA, Waggie KS, Durham JB, and Walker SE (1984). Sjogren's syndrome in MRL/I and MRL/n mice. Arthritis Rheum 27:157-165.

Humphreys-Beher MG (1996). Animal models for autoimmune disease-associated xerostomia and xerophthalmia. Adv Dent Res 10:73-75.

Humphreys-Beher MG, Hu Y, Nakagawa Y, Wang PL, and Purushotham KR (1994). Utilization of the non-obese diabetic (NOD) mouse as an animal model for the study of secondary Sjogren's syndrome. Adv Exp Med Biol 350:631-636.

Jansen A, Homo-Delarche F, Hooijkaas H, Leenen PJ, Dardenne M, Drexhage HA (1994). Immunohistochemical characterization of monocytes-macrophages and dendritic cells involved in the initiation of the insulitis and beta-cell destruction in NOD mice. Diabetes 43:667-675.

Jonsson R, Tarkowski A, Backman K, Holmdahl R, and Klareskog $L$ (1987). Sialadenitis in the MRL-I mouse: Morphological and immunohistochemical characterization of resident and infiltrating cells. Immunology 60:611-616.

Ledbetter JA and Herzenberg LA (1979). Xenogeneic monoclonal antibodies to mouse lymphoid differentiation antigens. Immunol Rev 47:63-90.

Lo D, Reilly CR, Scott B, Liblau R, McDevitt HO, and Burkly LC (1993). Antigen- presenting cells in adoptively transferred and spontaneous autoimmune diabetes. Eur $\mathrm{J}$ Immunol 23: 1693-1698.

Ludewig B, Odermatt B, Landmann S, Hengartner $\mathrm{H}$, and Zinkernagel RM (1998). Dendritic cells induce autoimmune diabetes and maintain disease via de novo formation of local lymphoid tissue. J Exp Med 188:1493-1501.
Malorny U, Michels E, and Sorg C (1986). A monoclonal antibody against an antigen present on mouse macrophages and absent from monocytes. Cell Tissue Res 243:421-428.

Metlay JP, Witmer-Pack MD, Agger R, Crowley MT, Lawless $D$, and Steinman RM (1990). The distinct leukocyte integrins of mouse spleen dendritic cells as identified with new hamster monoclonal antibodies. J Exp Med 171:1753-1771.

Mooij P, de Wit HJ, and Drexhage HA (1993). An excess of dietary iodine accelerates the development of a thyroidassociated lymphoid tissue in autoimmune prone BB rats. Clin Immunol Immunopathol 69:189-198.

Oxholm P, Daniels TE, and Bendtzen K (1992). Cytokine expression in labial salivary glands from patients with primary Sjogren's syndrome. Autoimmunity 12:185-191.

Peters JH, Gieseler R, Thiele B, and Steinbach F (1996). Dendritic cells: From ontogenetic orphans to myelomonocytic descendants. Immunol Today 17:273-278.

Robinson CP, Yamamoto $\mathrm{H}$, Peck AB, and HumphreysBeher MG (1996). Genetically programmed development of salivary gland abnormalities in the NOD (nonobese diabetic)SCID mouse in the absence of detectable lymphocytic infiltration: A potential trigger for sialoadenitis of NOD mice. Clin Immunol Immunopathol 79:50-59.

Rosmalen JG, Leenen PJ, Katz JD, Voerman JS, and Drexhage HA (1997). Dendritic cells in the autoimmune insulitis in NOD mouse models of diabetes. Adv Exp Med Biol 417:291294.

Shultz LD, Schweitzer PA, Christianson SW, Gott B, Schweitzer IB, Tennent B, McKenna S, Mobraaten L, Rajan TV, Greiner DL, and Leiter EH (1995). Multiple defects in innate and adaptive immunologic function in NOD/LtSz-SCID mice. J Immunol 154:180-191.

Simons PJ, Delemarre FG, Jeucken PH, and Drexhage HA (1998). Pre-autoimmune thyroid abnormalities in the biobreeding diabetes-prone (BB-DP) rat: A possible relation with the intrathyroid accumulation of dendritic cells and the initiation of the thyroid autoimmune response. J Endocrinol 157:43-51.

Sozzani S, Luini W, Borsatti A, Polentarutti N, Zhou D, Piemonti L, D'Amico G, Power CA, Wells TN, Gobbi M, Allavena P, Mantovani A (1997). Receptor expression and responsiveness of human dendritic cells to a defined set of CC and CXC chemokines. J Immunol 159:1993-2000.

Stingl G and Bergstresser PR (1995). Dendritic cells: A major story unfolds. Immunol Today 16:330-333.

Stott DI, Hiepe F, Hummel M, Steinhauser G, and Berek C (1998). Antigen-driven clonal proliferation of $B$ cells within the target tissue of an autoimmune disease. The salivary glands of patients with Sjogren's syndrome. J Clin Invest 102:938-946.

Tengner $\mathrm{P}$, Halse AK, Haga HJ, Jonsson R, and WahrenHerlenius M (1998). Detection of anti-Ro/SSA and anti-La/ SSB autoantibody-producing cells in salivary glands from patients with Sjögren's syndrome. Arthritis Rheum 41:22382248.

Tomonari K (1988). A rat antibody against a structure functionally related to the mouse T-cell receptor/T3 complex. Immunogenetics 28:455-458.

Voorbij HA, Jeucken PH, Kabel PJ, De Haan M, and Drexhage HA (1989). Dendritic cells and scavenger macrophages in pancreatic islets of prediabetic BB rats. Diabetes 38:16231629. 
Voorbij HA, Kabel PJ, de Haan M, Jeucken PH, van der Gaag RD, de Baets MH, and Drexhage HA (1990). Dendritic cells and class II MHC expression on thyrocytes during the autoimmune thyroid disease of the BB rat. Clin Immunol Immunopathol 55:9-22.

Watson LM, Rao JK, Gilkeson GS, Ruiz P, Eicher EM, Pisetsky DS, Matsuzawa A, Rochelle JM, and Seldin MF (1992). Genetic analysis of MRL/Ipr mice: Relationship of the Fas apoptosis gene to disease manifestations and renal disease-modifying loci. J Exp Med 176:1645-1656.

Wu J, Zhou T, Zhang J, He J, Gause WC, and Mountz JD (1994). Correction of accelerated autoimmune disease by early replacement of the mutated Ipr gene with the normal Fas apoptosis gene in the T cells of transgenic MRL-Ipr/lpr mice. Proc Natl Acad Sci U S A 91:2344-2348.
Xu LL, Warren MK, Rose WL, Gong W, and Wang JM (1996). Human recombinant monocyte chemotactic protein and other $\mathrm{C}-\mathrm{C}$ chemokines bind and induce directional migration of dendritic cells in vitro. J Leukoc Biol 60:365-371.

Yanagi K, Haneji N, Ishimaru N, Saito I, and Hayashi Y (1997). Analysis of $\mathrm{T}$ cell receptor Vbeta usage in the autoimmune sialadenitis of non-obese diabetic (NOD) mice. Clin Exp Immunol 110:440-446.

Zanella M, Lukas M, Koch F, Fritsch P, Schuler G, and Romani N (1996). Cytokine requirements for the emigration of cutaneous dendritic cells from the skin: Studies in a skin organ culture model. Arch Dermatol Res 288:284. 